\title{
Effects of leech salivary extract (lse) on indices of liver function in rats
}

\author{
Ojo Olufunmilola Praise ${ }^{1}$, Hausatu Babayi ${ }^{1 *}$, Israel Kayode Olayemi², Oladosun Oluwale Peter ${ }^{3}$, Labake FadikpeAjoke $^{4}$ and Elisha Baba $^{5}$ \\ ${ }^{1}$ Department of Microbiology, Federal University of Technology Minna, Niger, Minna, Niger State \\ ${ }^{2}$ Department of Biological Sciences, Federal University of Technology Minna, Niger, Minna, Niger State \\ ${ }^{3}$ Department of Chemistry, Federal University of Technology Minna, Niger, Minna, Niger State \\ ${ }^{4}$ Clinic, National Institute for Pharmaceutical Research Development, Idu-Abuja, Nigeria
}

\begin{abstract}
This study was carried out to establish the safety status of leech salivary extract (LSE) for potential administration in clinical conditions, where found potent against causative microbes. Sub-chronic toxicity test of LSE was carried out by oral administration of 25,50 and $100 \mathrm{mg} / \mathrm{kgbw}$ to healthy wister rats (Rattus novergicus) for 28 days, with appropriate immune suppressant (Dexamethasone) and immune stimulant (Jobelyn) and negative controls. Blood samples were collected from the rats and analysed for metabolite parameters including, Aspartate amino transferase (AST), Alanine transaminase (ALT), Alkaline phosphatase (ALP) and Total protein, following standard procedures. Histopathological examination of liver harvested from the rats, post sacrifice, involved grossing and tissue processing. The results revealed that the LSE had no significant $(\mathrm{p}>0.05)$ effect on the biomarkers of the hepatic function (AST, ALT and total protein) but ALP significantly ( $<<0.05$ ) decreased from control concentration of $226.20 \pm 22.35$ to $141.00 \pm 15.25$ at $50 \mathrm{mg} / \mathrm{kgbw}$ and $226.20 \pm 22.35$ to $118.40 \pm 18.48$ at $100 \mathrm{mg} / \mathrm{kgbw}$. The histologic sections of the liver showed normal hepatic morphology. These findings revealed that the LSE has no potential to cause cell damage but caution should be taken when administering LSE for a long duration.
\end{abstract}

\section{Introduction}

Biochemical analyses are useful in chronic toxicity studies because they serve as indicators of cell damage when enzymes are leaked into the blood as a result of exposure of the cell to certain chemical compounds [1]. Aspartate transaminase (AST) formally called serum glutamate oxaloacetate transaminase (SGOT) is a marker enzyme found in many tissues including the liver, kidney, muscle, heart, brain and lung. The amount of AST in the blood relates to the extent of tissue damage. Alanine transaminase (ALT) is another parameter used to assess liver ill health. It is a marker enzyme formally known as serum glutamate-pyruvate transaminase (SGPT). ALT is the most common enzyme in the liver but can also be found in the plasma. Elevated levels of ALT is an indicator of medical conditions such as hepatitis, liver damage, diabetes, congestive heart disease or bile duct problems [2]. Alkaline phosphatase (ALP) is a hydrolase which removes phosphate group from many types of molecules. ALP is also a marker enzyme of the plasma membrane and endoplasmic reticulum, a by-product of osteoblast activity and an enzyme present in the cells lining the bile duct of the gall bladder in the liver [3]. It also functions in splitting cholesterol and long chain fatty acids [4]. An elevated level of ALP is an indication of an alteration in the permeability of the plasma membrane and obstruction of the bile duct [5]. Serum total protein is an indicator for measuring the total amount of protein in the serum. Proteins are important building blocks of all cells needed for the body's growth, development and health.

\section{Materials and methods}

\section{Laboratory animals}

Healthy Wister rats (Rattus novergicus) of the same weight group $(120-200 \mathrm{~g})$ were used in acute and sub-chronic investigations. The animals were obtained from the Animal House of the Department of Biochemistry, Faculty of Natural Sciences, Ibrahim Badamasi Babangida University Lapai, Nigeria. They were housed in stainless steel cages bedded with dry clean wood shavings, maintained at a temperature of $25 \pm 2^{\circ} \mathrm{C}$ and observed under 12-hour light/dark cycle, in a well ventilated room, for 2 weeks before the commencement of the experiment. The rats were fed with standard animal feeds (Bendel feeds and flour mills, Edo State, Nigeria) and tap water ad libitum. The cages were cleaned and disinfected regularly. Soiled wood shavings were replaced often. The feed, water containers were washed regularly. The animals were housed and cared for in accordance with Good Laboratory Practice (GLP) regulations of WHO (1998). The principles of Laboratory Animal Care [6] was also be followed throughout the study.

\section{Toxicological studies}

The sub-chronic toxicity study of the LSE was conducted as described by Aniagu et al. [7]. The studies included the evaluation of the effects of LSE on plasma biochemical parameters.

\section{Sub-chronic toxicity studies of active leech salivary extract}

The method described by Aniagu et al. [7] was employed in the sub-chronic toxicity test of the LSE. Thirty rats (30) were selected and

Correspondence to: Hausatu Babayi, Department of Microbiology, Federal University of Technology Minna, Niger, Minna, Niger State, E-mail: acadbabayi@ yahoo.com

Key words: AST, ALT, ALP, total protein, histopathology

Received: January 10, 2018; Accepted: January 29, 2018; Published: January 31, 2018 
divided into six (6) groups of five rats each. Three of the groups were given $25 \mathrm{mg} / \mathrm{kgbw}, 50 \mathrm{mg} / \mathrm{kgbw}$ and $100 \mathrm{mg} / \mathrm{kgbw}$ of LSE orally for 28days. The 4th group served as immune suppressant group which was administered with dexamethasone dose, the 5 th as immune stimulant group administered with jobelyn dose and the 6 th as Control which was only fed with the standard water. The body weight of the rats was taken once before dosing commenced, once weekly during dosing and on sacrifice day. The effect of the LSE on plasma biochemical parameters (alanine transaminase (ALT), aspartate transaminase (AST), alkaline phosphatase (ALP) and total cholesterol (TC)), were also determined using commercial kits obtained from Radox Laboratory, UK.

\section{Collection of blood, serum and organs}

The collection of blood, serum and organ samples were as described by Shittu et al. [8]. At the end of the four weeks treatment, the animals were starved but still had water ad libitum for 24 hours before they were sacrificed under diethyl ether anesthesia. The blood was collected in a clean, EDTA- free (plain) tubes which were allowed to stand for 10 minutes at room temperature before been centrifuged at $1000 \mathrm{rpm}$ for 15 minutes to obtain the serum. The animals were, thereafter, quickly dissected and the liver was removed, cleaned and weighed. The liver was then fixed in $10 \%$ formalin solution.

\section{Histopathological studies}

The histopathological examination of the liver was done as described by Krause [9]. This involved two main stages: grossing and tissue processing.

\section{Statistical analysis}

Results were expressed as mean value \pm standard error mean (SEM). Among groups, comparisons of means were performed by the Analysis of Variance (ANOVA) test, for statistical significance of differences, at $\mathrm{p}=0.05$. The means were subsequently separated using Duncan Multiple Range Test (DMRT. All data analysis were done using the statistical package SPSS version 19.0.

\section{Results}

\section{Effect of leech salivary extract on the liver function of rats}

The effects of chronic administration of increasing concentrations of LSE on the activities of some biomarker enzymes and total protein in the treated rats are shown in Table 1 . There was an insignificant $(\mathrm{p}>0.05)$ reduction in aspartate amino transferase (AST) level in the groups administered $25 \mathrm{mg} / \mathrm{kgbw}$ and jobelyn (4.17) and an insignificant $(\mathrm{p}>0.05)$ elevation in the $50 \mathrm{mg} / \mathrm{kgbw}$ and dexamethasone (3) groups. However, significant $(\mathrm{p}<0.05)$ elevation in AST was recorded in the 100 $\mathrm{mg} / \mathrm{kgbw}$ LSE group compared with the Control. The LSE as well as dexamethasone (3) and jobelyn (4.17) insignificantly ( $\mathrm{p}>0.05)$ reduced the alanine transaminase (ALT) level when compared with control. On the other hand, the alkaline phosphatase (ALP) level decreased significantly $(\mathrm{p}<0.05)$ in rat groups administered $50 \mathrm{mg} / \mathrm{kgbw}$ and $100 \mathrm{mg} / \mathrm{kgbw}$ LSE, as well as, jobelyn (4.17) groups. However, only insignificantly ( $>0.05$ ) decreases were recorded in the $25 \mathrm{mg} / \mathrm{kgbw}$ LSE and dexamethasone (3) groups. The total protein level, on its part, increased insignificantly ( $>0.05)$ across the groups, except $50 \mathrm{mg} /$ kgbw LSE group which had an insignificant $(\mathrm{p}>0.05)$ reduction when compared with Control.

\section{Effect of crude leech salivary extract on histology of rats}

Plate IA showed the histology of liver of the Control rats while plate IB showed for the rats exposed to LSE for 28 days. The results of

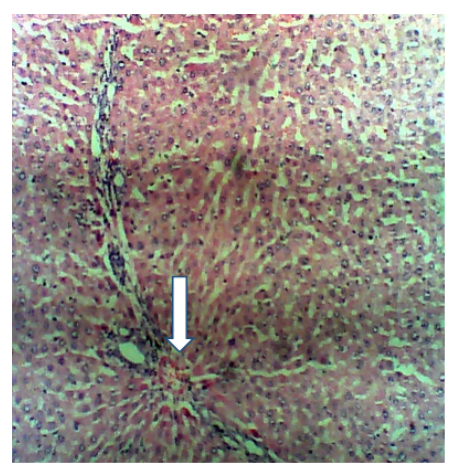

A

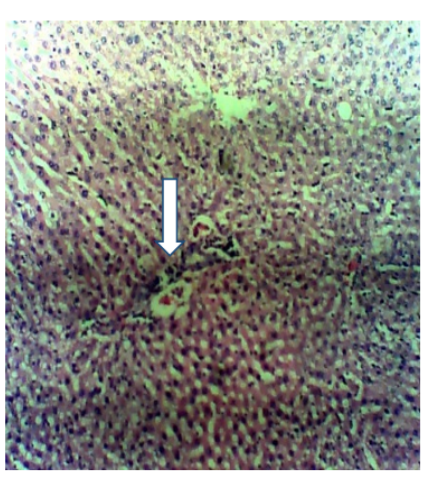

B
Plate I. Histology of liver of rat (A: Control rat; B: Rat treated with LSE).

Table 1. Effects of Leech Salivary Extract on the liver function of rats.

\begin{tabular}{|c|c|c|c|c|}
\hline $\begin{array}{l}\text { Treatments } \\
(\mathrm{mg} / \text { kgbw) }\end{array}$ & $\operatorname{AST}(\mathrm{U} / \mathrm{L})$ & $\operatorname{ALT}(\mathbf{U} / \mathbf{L})$ & $\operatorname{ALP}(\mathbf{U} / L)$ & $\begin{array}{l}\text { Total protein } \\
\text { (g/dL) }\end{array}$ \\
\hline Control & $51.00 \pm 7.60 \mathrm{a}^{*}$ & $40.60 \pm 0.74 \mathrm{a}$ & $226.20 \pm 22.35 \mathrm{~d}$ & $7.49 \pm 1.14 \mathrm{a}$ \\
\hline 25 & $47.80 \pm 12.10 \mathrm{ab}$ & $39.00 \pm 0.77 \mathrm{a}$ & $158.60 \pm 13.68 \mathrm{~cd}$ & $7.67 \pm 0.39 \mathrm{a}$ \\
\hline 50 & $67.80 \pm 5.32 \mathrm{a}$ & $38.200 \pm 0.37 \mathrm{a}$ & $141.00 \pm 15.25 \mathrm{c}$ & $7.40 \pm 0.61 \mathrm{a}$ \\
\hline 100 & $81.00 \pm 9.75 b$ & $39.20 \pm 0.73 a$ & $118.40 \pm 18.48 b$ & $7.76 \pm 1.13 a$ \\
\hline $\begin{array}{l}\text { Dexamethasone } \\
\text { (3) }\end{array}$ & $51.20 \pm 6.23 \mathrm{a}$ & $38.92 \pm 1.21 \mathrm{a}$ & $160.20 \pm 16.52 \mathrm{~cd}$ & $8.12 \pm 0.37 \mathrm{a}$ \\
\hline Jobelyn (4.17) & $46.00 \pm 7.91 \mathrm{a}$ & $40.00 \pm 0.54 \mathrm{a}$ & $72.40 \pm 19.63 a$ & $8.08 \pm 0.57 \mathrm{a}$ \\
\hline \multicolumn{5}{|c|}{$\begin{array}{l}\text { Values are means } \pm \text { SEM for } n=5 \\
\text { *Values along the same column with different superscripts are significantly different from } \\
\text { each other }(p<0.05) \text {. } \\
\text { AST: Aspartate amino transferase } \\
\text { ALT: Alanine transaminase } \\
\text { ALP: Alkaline phosphatase } \\
\text { mg/kgbw: Milligram per kilogram body weight } \\
\text { U/L: Units per liter } \\
\text { g/dL: Gram per deciliter }\end{array}$} \\
\hline
\end{tabular}

the present study revealed that there was normal architectures in the liver of rats administered $25 \mathrm{mg} / \mathrm{kgbw}$ LSE but at higher doses $(50 \mathrm{mg} /$ $\mathrm{kgbw}$ and $100 \mathrm{mg} / \mathrm{kgbw}$ ), it showed moderate portal inflammation with interphase hepatitis.

\section{Discussion}

The results obtained from the present study showed a significant increase in AST level in rats administered $100 \mathrm{mg} / \mathrm{kgbw}$ LSE when compared with Control. Adeyemi et al. [10] reported that the increase in AST levels may have occurred as a result of metabolism of yoyo bitters by the liver in response to overcoming the stress induced by yoyo bitters. This suggests that chronic exposure to LSE at higher dose may be associated with hepatoxicity. However, dose-dependent fluctuations were observed in the AST values between treatments which may indicate a rise in AST resulting from cell death in response to exposure of the rats to the extract and a gradual tissue repair as a result of damage caused by exposure to extract. This findings corroborate with the studies of Kabiru et al. [11] who suggested that AST levels fluctuates in response to the extent of cell death and therefore may be temporarily and minimally elevated early in disease process and extremely elevated during the most active phase.

Compared with AST, ALT is a more specific indicator of liver inflammation (Hyder et al., [12]). From the present study, it was observed that the extract did not exert any significant toxic effect on the ALT levels of rats across all treatment groups. However, the administration of LSE in the present study led to a significant decrease in ALP level in rats administered $50 \mathrm{mg} / \mathrm{kgbw}$ and $100 \mathrm{mg} / \mathrm{kgbw} \mathrm{LSE}$ as 
well as jobelyn when compared with Control. The extract did not exert any delirious effect on the total protein level of the rats in all treated groups when compared with the Control. Histological assessment is critical to ascertaining any damage to tissues as a result of chronic exposure to extract. However, the result of the histologic sections of the liver obtained in the present study revealed that the liver tissues of the treated animals and control showed normal hepatic morphology. This result is in harmony with the relative organ weight and biomarkers of the hepatic function (AST, ALT and total protein) which showed insignificant $(\mathrm{p}>0.05)$ difference in rats exposed to LSE when compared with control. This result corroborated reports of Manpreet et al. [13] which stated that Lawsonia inermis when administered to rats showed normal liver architecture implying that the extract is non-toxic to the liver.

\section{Conclusion}

The present study revealed that, the chronic administration of the LSE did not exert any toxic effects on the serum total protein, aspartate amino transferase (AST) and alanine transaminase (ALT) concentration but decreased the alkaline phosphate (ALP) concentration at $50 \mathrm{mg} /$ kgbw and $100 \mathrm{mg} / \mathrm{kgbw}$.

\section{Acknowledgement}

The authors wish to acknowledge the facilities made available by the Departments of Microbiology and Biochemistry, Federal university of Technology, Minna, and Gwagwalada Specialist Hospital, Abuja, Nigeria for the accomplishment of this research.

\section{References}

1. Rochling F (2001) Evaluation of Abnormal Liver Tests. Clin Cornerstone 3: 1-12.
2. Lee T, Kim W, Poterucha J (2012) Evaluation of Elevated Liver Enzymes. Clin Liver Dis 16: 183-198. [Crossref]

3. Shahjahan M, Sabitha K, Jainu M, Shymala Devi C (2004) Effects of Solanum trilobatum against carbon tetrachloride-induced hepatic damage in albino rats. Indian J Med Res 120: 194-198. [Crossref]

4. Kaur V, Verma M, Kaur A, Gupta S, Singh K (2012) To establish the reference intervals of lipid profile in Punjab. Indian J Clin Biochem 27: 290-295. [Crossref]

5. John N, Shobana G, Keerthana K (2014) Protective effect of Coriander sativum L. on cadmium induced toxicity in albino rats. World Journal of Pharmacy and Pharmaceutical Sciences 3: 525-534.

6. National Institute of Environmental Health Sciences - NIEHS (1985) "Respect for life".

7. Aniagu S, Nwinyi C, Akumka D, Ajoku G, Izebe K, et al. (2005) Toxicological studies in Rats Fed Nature Cure Bitters. Afr J Biotechnol 4: 72-78.

8. Shittu O, Lawal B, Blessing U, Haruna G, Abubakar A, et al. (2015) Alteration in Biochemical Indices Following Chronic Administration of Methanolic Extract of Nigeria Bee Propolis in Wister Rats. Asian Pacific journal of tropical disease 5: 654657.

9. Krause WJ (2001) The Art of Examining and Interpreting Histologic Preparations. A Student Handbook. UK. Partheton Publishing Group 9-10.

10. Adeyemi O, Fambegbe M, Daniyan O, Nwajei I (2012) Yoyo Bitters, a polyherbal formulation influenced some biochemical parameters in Wistar rats. $J$ Basic Clin Physiol Pharmacol 23: 135-138. [Crossref]

11. Kabiru Y, Okogun J, Gbodi T, Makun H, Obgadoyi E (2013) Subchronic Toxicity Studies of Methanolic Extract of Eucalyptus camaldulensis (Leaf) In Wister Rats. Ios Journal of Pharmacy 3: 38-45.

12. Hyder M, Hasan M, Mohieldein A (2013) Comparative Levels of ALT, AST, ALP and GGT in Liver associated Diseases. Eur J Exp Bio 3: 280-284.

13. Manpreet K, Dangi C, Singhai A, Singh M, Kosta S, et al. (2014) Toxicity profile of ethanolic extract of Lawsonia inermis leaves in albino wister rats. World Journal of Pharmacy and Pharmaceutical Sciences 3: 835-848.

Copyright: (C2018 Praise OO. This is an open-access article distributed under the terms of the Creative Commons Attribution License, which permits unrestricted use, distribution, and reproduction in any medium, provided the original author and source are credited. 